\title{
RESISTANCE OF S. AUREUS ATCC 25923, E. COLI 055K59 No. 3912/41 AND P. AERUGINOSA 27/99 TO THE WASH-DISINFECTANT «MILKODEZ»
}

\author{
Mykola Verkholiuk ${ }^{1}$ \\ verkholiuk91@gmail.com \\ Ruslan Peleno ${ }^{1}$ \\ andriyovich30@ukr.net \\ Iaromyr Turko ${ }^{1}$ \\ 2008pik@gmail.com
}

${ }^{1}$ Stepan Gzhytskyi National University of Veterinary Medicine and Biotechnologies Lviv 50 Pekarskaya str., Lviv, Ukraine, 79010

\begin{abstract}
The aim of the work - the article presents the results of determining of the resistance of S. aureus ATCC 25923, E. coli 055K59 No. 3912/4 and P. aeruginosa 27/99 test cultures in planktonic form and in biofilm to our developed «Milkodez» acid detergent.

Materials and methods. Microbial biofilms were grown on MPB in $5 \mathrm{~cm}$ disposable plastic Petri dishes. To determine the effect of disinfectants on microbial biofilms, 3 Petri dishes with biofilms of each of the test cultures were used. One of the Petri dishes served as control and she had for 15 minutes made $5 \mathrm{~cm}^{3}$ of saline $\mathrm{NaCl}$ solution, in the second $-5 \mathrm{~cm}^{3}$ of hot water $\left(\mathrm{t}=70 \pm 5{ }^{\circ} \mathrm{C}\right)$, and in the third $-5 \mathrm{~cm}^{3}$ of acidic detergent «Milkodez». Microbial biofilms were fixed for $10 \mathrm{~min} .96^{\circ}$ with ethyl alcohol for 10 min. were stained with a $0.1 \%$ solution of crystalline violet, and the remnants of the unabsorbed paint were removed with phosphate buffer. The biofilm dye was extracted with $96^{\circ}$ of ethyl alcohol, which was photocolometrically investigated at $570 \mathrm{~nm}$ to establish the density of the formed biofilms. The density of the formed microbial biofilms was considered low in optical density of the extract up to 0.5 units, average - from 0.5 to 1.0 units; and high - over 1.0 units

The resistance of planktonic forms of test cultures of microorganisms to disinfectants was determined in sterile tubes, which made $10 \mathrm{~cm}^{3}\left(\mathrm{t}=70 \pm 5^{\circ} \mathrm{C}\right)$ of $0.5 \%$ of their working solutions and $0.1 \mathrm{~cm}^{3}$ ( 1 billion microbial bodies) of the standard test - cultures. The culture was maintained for $15 \mathrm{~min}$. and made ten - fold plantings on IPA in Petri dishes.

Incubation of mesophilic microorganisms was carried out in a thermostat at a temperature of $30{ }^{\circ} \mathrm{C}$, and psychrophilic $-20^{\circ} \mathrm{C}$. After 48 hours the calculation of the growing colonies were carried out. The results were expressed in colony forming units (CFU).

Results. Due to the impact on microbial biofilms formed by the test cultures of S. aureus ATCC 25923, E. coli 055K59 No. 3912/41 and P. aeruginosa $27 / 99$ for $15 \mathrm{~min} .0 .5 \%$ solution of acid detergent «Milkodez» the optical density of the solutions was respectively $0.64,0.72,0.45$ units. The results obtained indicate that the melkodez caused a decrease in the biofilm-forming ability of S. aureus ATCC 259233.2 times, in E. coli 055K59 No. 3912/41 - 1,7 times and in P. aeruginosa 27/99 - 2.8 times, compared to control. However, the density of one - day microbial biofilms formed by S. aureus ATCC 25923 and E. coli 055K59 No. 3912/41 was medium, and P. aeruginosa $27 / 99$ was low. It has been proven that the «Milkodez» acid detergent developed is more effective than the prototype «Hypracid», since it caused the death of $100 \%$ of planktonic test cultures and the number of S. aureus ATCC 25923, E. coli $055 \mathrm{~K} 59$ No. 3912/41 and P. aeruginosa 27/99 formed in the biofilm that survived after its application was 2.7, 3.2 and 1.4 times lower, respectively.

Conclusions. It was found that the test cultures were able to form high - density biofilms, since the optical density of the extract in the control was in the range from 1.28 to 2.05 units, which is greater than 1.0 units. Acid wash detergent «Milkodez» for 15 minutes of exposure causes the formation of S. aureus ATCC 25923, E. coli 055K59 No. 3912/41 and P. aeruginosa 27/99 biofilms of low and medium density and reduces their biofilm capacity by 3.2, 1.7 and 2.8 times, respectively. Its use provides the death of $100 \%$ of the planktonic forms of the test cultures under study and reduces their number in the biofilm by 2.7, 3.2 and 1,4 times more, respectively, compared to «Hypracid» detergent.
\end{abstract}

Keywords: S. aureus ATCC 25923, E. coli 055K59 No. 3912/4, P. aeruginosa 27/99, biofilms, «Milkodez».

DOI: $10.21303 / 2504-5679.2020 .001100$

\section{Introduction}

In modern conditions of milk production, the decisive factor affecting its quality is the sanitary condition of milking equipment $[1,2]$. The main share of mechanical and bacterial con- 
tamination of milk is formed due to insufficiently washed milking equipment and milk equipment [3]. Due to its exploitation, various composition and properties of deposits are formed on the inner surfaces of pipelines, which are an excellent medium for the development of microorganisms [4, 5]. Most of these surfaces are closed and have limited access to cleaning and disinfection. In case of insufficiently effective sanitary treatment, the development of microflora occurs, which enters the next batch of milk, which significantly degrades its safety and quality [6]. As a result, the grade and, consequently, the sale price decrease $[7,8]$.

It is known that microorganisms are able to survive on abiotic surfaces of dairy equipment due to their extremely important property - the ability to form biofilms [9, 10]. A biofilm is a living collection of several types of bacteria that is constantly updated, attached to a biogenic or abiogenic surface and surrounded by a polysaccharide matrix, which is a stable structure and is one of the important factors for bacterial protection $[11,12]$.

The formation of the biofilm adversely affects the quality of the milk obtained and the safety of the finished product since, in addition to saprophytes, pathogens can also be involved in them $[13,14]$. This complex process involves the formation of micro-colonies, structuring and their maturation, which significantly increases the survival of bacteria in the body and the environment $[15,16]$. Microbial resistance in a biofilm is determined by different gene expression in a multicellular population, which causes some cells to transition to a persistent state, which in turn causes inherited resistance or tolerance to different antimicrobials [17, 18].

According to Verran J. (2010), bacterial resistance in biofilms to disinfectants is about 100 times greater than that of planktonic microorganisms. This is due to the fact that the bacteria in the biofilms are in a metabolically inert state, causing them to have poor antimicrobial agents, and because the pores and channels of the biofilms do not allow large molecules of disinfectants to enter the biofilm [19].

That is why, in the development of detergents for sanitary processing of milking equipment, it is necessary to select such active substances that would destroy the intercellular polysaccharide peptide matrix of the biofilm and adversely affect not only planktonic cultures of microorganisms, but also on bacteria.

The aim of our work was to investigate the resistance of $S$. aureus ATCC 25923, E. coli 055K59 No. 3912/4 and P. aeruginosa 27/99 test cultures in planktonic form and in biofilm to our developed «Milkodez» acid detergent.

\section{Materials and Methods}

The researches were conducted at the department of microbiology and virology, Stepan Gzhytskyi National University of Veterinary Medicine and Biotechnologies Lviv, and Ternopil Research Station of the Institute of Veterinary Medicine of NAAS of Ukraine during 2018-2019.

Using in vitro experiments, we studied the effect of acidic detergent «Milkodez» on planktonic forms of $S$. aureus ATCC 25923, E. coli 055K59 No. 3912/4 and P. aeruginosa $27 / 99$ and daily microbial biofilms formed by these test cultures. As a prototype used registered in Ukraine acidic agent «Hypracid». To obtain microbial biofilms, $5 \mathrm{~cm}^{3}$ of meat-peptone broth and $1 \mathrm{~cm}^{3}$ (10 thousand CFU in $1 \mathrm{~cm}^{3}$ ) of daily bacterial test culture were introduced into disposable $5 \mathrm{~cm}$ plastic Petri dishes. After incubation for 24 hours the contents of the cups were poured into the solution. To remove planktonic (unattached) bacteria, the cups were washed three times with sterile phosphate buffer and kept at room temperature until complete drying of the contents.

The effect of «Milkodez» on microbial biofilms was investigated on three Petri dishes with biofilms formed by the test cultures. In the first cup with the biofilm of the corresponding test culture, which served as a control, $5 \mathrm{~cm}^{3}$ of saline $\mathrm{NaCl}$ was introduced, in the second $-5 \mathrm{~cm}^{3}$ of hot water $\left(\mathrm{t}=70 \pm 5^{\circ} \mathrm{C}\right)$, and in the third $-5 \mathrm{~cm}^{3}$ of acid detergent $«$ Milkodez» $\left(\mathrm{t}=70 \pm 5^{\circ} \mathrm{C}\right)$. The exposure was $15 \mathrm{~min}$. The contents of the cups were drained, the cup was washed with sterile phosphate buffer and kept at room temperature until complete drying. The microbial biofilms were then fixed for 10 minutes with $96^{\circ}$ ethyl alcohol. After decanting, they were again dried for 10 minutes; were stained with a $0.1 \%$ solution of crystalline violet. Removal of the residues of the non-adsorbed paint was carried out with phosphate buffer and dried again in air. The biofilm paint was extracted 
by application for 20 minutes $3 \mathrm{~cm}^{3}$ of $96^{\circ}$ ethyl alcohol. To determine the density of the formed biofilms photocolometrically at a wavelength of $570 \mathrm{~nm}$, determine the optical density of ethyl alcohol, which was carried out the extraction of paint [20]. The density of the formed microbial biofilms was considered low in optical density of the extract up to 0.5 units, average - from 0.5 to 1.0 units; and high - over 1.0 units [21].

To determine the resistance of microorganisms in daily biofilms to «Milkodez» and «Hypracid» in Petri dishes with pre-formed biofilms for 15 minutes $5 \mathrm{~cm}^{3}\left(\mathrm{t}=70 \pm 5^{\circ} \mathrm{C}\right)$ of their $0.5 \%$ solutions were added. The disinfectants were drained and the contents of the cup washed three times with phosphate buffer solution and $5 \mathrm{~cm}^{3}$ of sterile $\mathrm{NaCl}$ solution was added. The sterile swab was carefully washed from the walls and bottom of the cup microbial biofilm, selected $1 \mathrm{~cm}^{3}$ suspension from which did a number of ten fold dilutions. The determination of the stability of planktonic forms of test cultures of microorganisms to disinfectants was carried out in sterile tubes, which made $10 \mathrm{~cm}^{3}$ $\left(\mathrm{t}=70 \pm 5{ }^{\circ} \mathrm{C}\right)$ of $0.5 \%$ working solutions and $0.1 \mathrm{~cm}^{3}$ ( 1 billion microbial bodies) of the standard test cultures. The culture was maintained for 15 minutes and from the resulting slurry a number of ten fold dilutions were prepared. Crops from each dilution were carried out in Petri dishes, in which $1 \mathrm{~cm}^{3}$ of the suspension was introduced and filled with molten and cooled to $45 \pm 1{ }^{\circ} \mathrm{C}$ MPB [22].

Incubation of mesophilic microorganisms was carried out in a thermostat at a temperature of $30{ }^{\circ} \mathrm{C}$, and psychrophilic $-20^{\circ} \mathrm{C}$. After 48 hours the calculation of the growing colonies were carried out. The results were expressed in colony forming units (CFU).

The obtained numerical material was subjected to statistical processing by the method of variational statistics with determination of mean values and mean error. The probability of differences between the mean values during the analysis was evaluated using Student's t test ( $t)$. The difference between the values was considered probable when the probability of the difference was $\mathrm{p} \leq 0.05$.

\section{Results}

In Fig. 1 is shown the optical density of ethyl alcohol, which carried out the extraction of paint from bacterial biofilms formed S. aureus ATCC 25923, E. coli 055K59 No. 3912/41 and $P$. aeruginosa $27 / 99$, indicating that these test cultures are capable to form high-density biofilms, since the optical density of the extract in the control ranged from 1.28 to 2.05 units, which is greater than 1.0 units.

Processing of microbial biofilms for 15 minutes with hot water $\left(\mathrm{t}=70 \pm 5^{\circ} \mathrm{C}\right)$ caused a significant $(\mathrm{p} \leq 0.01)$ decrease in the optical density of the solutions. Thus, the optical density of the solution, by which biofilms were washed formed by $S$. aureus ATCC 25923 was 1,11 units, biofilms E. coli 055 K59 No. 3912/41 - 1.04 units and P. aeruginosa 27/99 - 0.83 units, which was $1.8,1.6$ and 1.5 times lower, respectively, compared to the control.

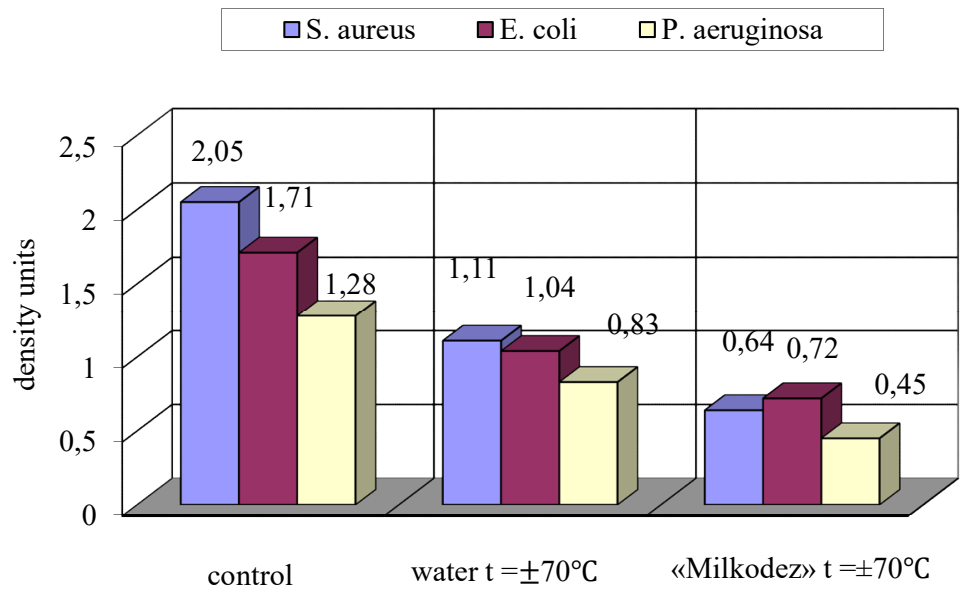

Fig. 1. The optical density of ethyl alcohol, which was carried out the extraction of paint from bacterial biofilms formed by the test cultures of $S$. aureus ATCC 25923,

E. coli $055 \mathrm{~K} 59$ No. $3912 / 41$ and $P$. aeruginosa $27 / 99$ 
Due to the impact on microbial biofilms formed by the test cultures of $S$. aureus ATCC 25923, E. coli $055 \mathrm{~K} 59$ No. 3912/41 and $P$. aeruginosa $27 / 99$ for $15 \mathrm{~min}$. $0.5 \%$ solution of acid detergent «Milkodez» the optical density of the solutions was respectively $0.64,0.72,0.45$ units. The results obtained indicate that the «Milkodez»caused a decrease in the biofilm-forming ability of $S$. aureus ATCC 259233.2 times, in E. coli 055K59 No. 3912/41 - 1.7 times and in P. aeruginosa 27/99 - 2.8 times, compared to control. However, the density of one - day microbial biofilms formed by S. aureus ATCC 25923 and E. coli $055 \mathrm{~K} 59$ No. 3912/41 was medium, and P. aeruginosa 27/99 was low.

Important in the study of new disinfectants is the study of the resistance to them of microorganisms, which are in planktonic form and formed into biofilms (Table 1).

\section{Table 1}

The resistance of the test cultures of microorganisms to working solutions of acidic agents «Milkodez» and «Hypracid», $\lg \mathrm{CFU} / \mathrm{cm}^{3}, \mathrm{M} \pm \mathrm{m}, \mathrm{n}=5$

\begin{tabular}{|c|c|c|c|c|}
\hline \multicolumn{2}{|c|}{ Microorganisms } & \multicolumn{3}{|c|}{ The number of microorganisms in $1 \mathrm{~cm}^{3}$ depends } \\
\hline & & Control & «Hypracid» & «Milkodez» \\
\hline \multirow{2}{*}{ S. aureus ATCC 25923} & planktonic & $7.08 \pm 0.351$ & $2.08 \pm 0.087^{*}$ & 0 \\
\hline & biofilm & $8.38 \pm 0.327$ & $4.97 \pm 0.192 *$ & $1.86 \pm 0.079 *$ o \\
\hline \multirow{2}{*}{ E. coli $055 \mathrm{~K} 59$ No. $3912 / 41$} & planktonic & $7.08 \pm 0.351$ & 0 & 0 \\
\hline & biofilm & $8.52 \pm 0.357$ & $4.87 \pm 0.162 *$ & $1.23 \pm 0.046^{*} \mathrm{o}$ \\
\hline \multirow{2}{*}{ P. aeruginosa $27 / 99$} & planktonic & $7.04 \pm 0.274$ & 0 & 0 \\
\hline & biofilm & $5.73 \pm 0.234$ & $3.15 \pm 0.122 *$ & $2.20 \pm 0.083 *$ o \\
\hline
\end{tabular}

Note: ${ }^{o}-p \leq 0.001-$ to the «Hypracid»; *-p $\leq 0.001-$ to control

It is established that the developed acidic detergent «Milkodez» in working concentration of $0.5 \%$, for exposures of 15 minutes caused the death of all test cultures of microorganisms that were in planktonic form. At the same exposure, the prototype agent «Hypracid» caused the death of planktonic forms E. coli 055K59 No. 3912/41 and P. aeruginosa 27/99 and showed a bactericidal effect against the $S$. aureus ATCC 25923 test culture, since their number decreased by $1 \mathrm{~cm}^{3}$, compared to the control, 3.4 times $(\mathrm{p} \leq 0.001)$ and amounted to $2.08 \pm 0.087 \mathrm{lg}$ CFU.

Biofilm to the acidic agent «Milkodez» indicate that for $15 \mathrm{~min}$ the exposure of its working solution did not ensure the death of all microorganisms. Thus, after the destruction of the biofilm formed $S$. aureus ATCC 25923, E. coli 055K59 No. 3912/41 and P. aeruginosa $27 / 99$ and sowing $1 \mathrm{~cm}^{3}$ of the resulting suspension on a nutrient medium, after 48 hours of incubation on it increased respectively $1.86 \pm 0.079,1.23 \pm 0.046$ and $2.20 \pm 0.083 \mathrm{lg}$ CFU. Compared to controls, the number of $S$. aureus ATCC 25923 was 4.5 times lower $(\mathrm{p} \leq 0.001)$, E. coli $055 \mathrm{~K} 59$ No. 3912/41 6.9 times, and $P$. aeruginosa $27 / 99-2.6$. times.

$P$. aeruginosa $27 / 99$ and the least resistant $S$. aureus ATCC 25923 were the least resistant of the tested test cultures formed into the biofilm to the «Hypracid» prototype preparation. S. aureus 25923 was $4.97 \pm 0.192 \mathrm{lg}$ CFU, E. coli $055 \mathrm{~K} 59$ No. $3912 / 41-4.87 \pm 0.162$ and P. aeruginosa $27 / 99-3.15 \pm 0.122 \mathrm{lg}$ CFU, which, compared to the control, was smaller respectively 40.7 , 42.8 and $45.1 \%(\mathrm{p} \leq 0.001)$.

It has been proven that the «Milkodez» acid detergent developed is more effective than the prototype «Hypracid», since it caused the death of $100 \%$ of planktonic test cultures and the number of $S$. aureus ATCC 25923, E. coli 055K59 No. 3912/41 and P. aeruginosa 27/99 formed in the biofilm that survived after its application was 2.7, 3.2 and 1.4 times lower, respectively. 


\section{Conclusion}

1. Acid detergent «Milkodez» for 15 minutes of exposure causes a decrease in biofilmforming capacity of $S$. aureus ATCC 259233.2 times, in E. coli 055 K59 No. 3912/41 - 1.7 times and in $P$. aeruginosa $27 / 99-2.8$ times and the formation of low biofilms and medium density.

2. The use of «Milkodez» provided $100 \%$ destruction of planktonic forms of $S$. aureus ATCC 25923, E. coli 055K59 No. 3912/41 and P. aeruginosa 27/99 and reduced their number in the biofilm by 2.7, 3.2 and 1.4 times more, respectively, compared to «Hypracid» detergent.

\section{References}

[1] Jacobs, J. A., Siegford, J. M. (2012). Invited review: The impact of automatic milking systems on dairy cow management, behavior, health, and welfare. Journal of Dairy Science, 95 (5), 2227-2247. doi: http://doi.org/10.3168/jds.2011-4943

[2] Janštová, B., Dračková, M., Dlesková, K., Cupáková, Š., Necidová, L., Navrátilová, P., Vorlová, L. (2011). Quality of raw milk from a farm with automatic milking system in the Czech Republic. Acta Veterinaria Brno, 80 (2), 207-214. doi: http://doi.org/ 10.2754/avb201180020207

[3] Palyi, A. (2015). Ynnovatsyonni podkhod v opredelenyy chystotu doylno-molochnoho oborudovanyia. Vestnyk NHAU, 1 (4). 161-166.

[4] Córdova, H. de A., Alessio, D. R. M., Cardozo, L. L., Thaler Neto, A. (2018). Impact of the factors of animal production and welfare on robotic milking frequency. Pesquisa Agropecuária Brasileira, 53 (2), 238-246. doi: http://doi.org/10.1590/s0100204x2018000200013

[5] Hickey, C. D., Sheehan, J. J., Wilkinson, M. G., Auty, M. A. E. (2015). Growth and location of bacterial colonies within dairy foods using microscopy techniques: a review. Frontiers in Microbiology, 6. doi: http://doi.org/10.3389/fmicb.2015.00099

[6] Gachak, Y. R., Mikhailitskaya, O. R., Gutyj, B. V., Kuzio, L. R., Beliak, V. I. (2019). Dairy products of treatment and prophylactic action with the new cryopowder. Scientific Messenger of LNU of Veterinary Medicine and Biotechnologies, 21 (91), 110-117. doi: http://doi.org/10.32718/nvlvet-f9119

[7] Fitzpatrick, S. R., Garvey, M., Jordan, K., Flynn, J., O’Brien, B., Gleeson, D. (2019). Screening commercial teat disinfectants against bacteria isolated from bovine milk using disk diffusion. Veterinary World, 12 (5), 629-637. doi: http://doi.org/10.14202/ vetworld.2019.629-637

[8] Alhussien, M. N., Dang, A. K. (2018). Milk somatic cells, factors influencing their release, future prospects, and practical utility in dairy animals: An overview. Veterinary World, 11 (5), 562-577. doi: http://doi.org/10.14202/vetworld.2018.562-577

[9] Seale, B., Bremer, P., Flint, S., Brooks, J., Palmer, J. (2015). Overview of the Problems Resulting from Biofilm Contamination in the Dairy Industry. Biofilms in the Dairy Industry. Chichester: John Wiley \& Sons, Ltd, 49-64. doi: http://doi.org/ 10.1002/9781118876282.ch4

[10] Vlková, H., Babák, V., Seydlová, R., Pavlík, I., Schlegelová, J. (2008). Biofilms and hygiene on dairy farms and in the dairy industry: sanitation chemical products and their effectiveness on biofilms - a review. Czech Journal of Food Sciences, 26 (5), 309-323. doi: http://doi.org/10.17221/1128-cjfs

[11] Costerton, W., Veeh, R., Shirtliff, M., Pasmore, M., Post, C., Ehrlich, G. (2003). The application of biofilm science to the study and control of chronic bacterial infections. Journal of Clinical Investigation, 112 (10), 1466-1477. doi: http://doi.org/10.1172/ jci200320365

[12] Majed, R., Faille, C., Kallassy, M., Gohar, M. (2016). Bacillus cereus Biofilms - Same, Only Different. Frontiers in Microbiology, 7. doi: http://doi.org/10.3389/fmicb.2016.01054

[13] Kukhtyn, M., Krushelnytska, N. (2014) Formuvannia bioplivok mikroorhanizmamy, yaki vydileni z doilnoho ustatkuvannia. Biolohiia tvaryn, 16 (1), 95-103.

[14] Ostrov, I., Paz, T., Shemesh, M. (2019). Robust Biofilm-Forming Bacillus Isolates from the Dairy Environment Demonstrate an Enhanced Resistance to Cleaning-in-Place Procedures. Foods, 8 (4), 134. doi: http://doi.org/10.3390/foods8040134

[15] Marchand, S., De Block, J., De Jonghe, V., Coorevits, A., Heyndrickx, M., Herman, L. (2012). Biofilm Formation in Milk Production and Processing Environments; Influence on Milk Quality and Safety. Comprehensive Reviews in Food Science and Food Safety, 11 (2), 133-147. doi: http://doi.org/10.1111/j.1541-4337.2011.00183.x

[16] Zhao, K., Tseng, B. S., Beckerman, B., Jin, F., Gibiansky, M. L., Harrison, J. J. et. al. (2013). Psl trails guide exploration and microcolony formation in Pseudomonas aeruginosa biofilms. Nature, 497 (7449), 388-391. doi: http://doi.org/10.1038/ nature 12155

[17] Singh, S., Singh, S. K., Chowdhury, I., Singh, R. (2017). Understanding the Mechanism of Bacterial Biofilms Resistance to Antimicrobial Agents. The Open Microbiology Journal, 11 (1), 53-62. doi: http://doi.org/10.2174/1874285801711010053 
[18] Lewis, K. (2001). Riddle of Biofilm Resistance. Antimicrobial Agents and Chemotherapy, 45 (4), 999-1007. doi: http://doi.org/ 10.1128/aac.45.4.999-1007.2001

[19] Verran, J., Packer, A., Kelly, P., Whitehead, K. A. (2010). The retention of bacteria on hygienic surfaces presenting scratches of microbial dimensions. Letters in Applied Microbiology, 50 (3), 258-263. doi: http://doi.org/10.1111/j.1472-765x.2009.02784.x

[20] Hall-Stoodley, L., Costerton, J. W., Stoodley, P. (2004). Bacterial biofilms: from the Natural environment to infectious diseases. Nature Reviews Microbiology, 2 (2), 95-108. doi: http://doi.org/10.1038/nrmicro821

[21] Stepanović, S., Vuković, D., Dakić, I., Savić, B., Švabić-Vlahović, M. (2000). A modified microtiter-plate test for quantification of staphylococcal biofilm formation. Journal of Microbiological Methods, 40 (2), 175-179. doi: http://doi.org/10.1016/ s0167-7012(00)00122-6

[22] Kukhtyn, M., Berhilevych, O., Kravcheniuk, K., Shynkaruk, O., Horyuk, Y., Semaniuk, N. (2017). The influence of disinfectants on microbial biofilms of dairy equipment. EUREKA: Life Sciences, 5, 11-17. doi: http://doi.org/10.21303/25045695.2017.00423 